Notre Dame Law School

NDLScholarship

Journal Articles

Publications

2018

Remedies, Meet Economics; Economics, Meet Remedies

Samuel L. Bray

Follow this and additional works at: https://scholarship.law.nd.edu/law_faculty_scholarship

Part of the Law and Economics Commons 


\title{
Remedies, Meet Economics; Economics, Meet Remedies
}

\author{
Samuel L. Bray`
}

\begin{abstract}
One would expect the fields of 'law and economics' and 'remedies' to have substantial interaction, but scholars in each field largely ignore those in the other. Thus, law and economics scholars blunder in their description of the law of remedies, and remedies scholars are cut off from economic insights. For scholars who are in these fields, this article offers a critique, as well as suggestions for cooperation. For all legal scholars interested in melding conceptual and economic analysis, it offers a cautionary tale of disciplinary fragmentation.
\end{abstract}

Keywords: remedies, economics, equity, injunctions

\section{Introduction}

One of the dominant influences on US legal scholarship in the last half century has been economic analysis. ${ }^{1}$ In that same span of time, a new field of legal scholarship has emerged in the United States, called 'remedies'. ${ }^{2}$ These have been distinctively American developments. 'Law and economics' has had less influence among English legal scholars, and scholarship on remedies has largely been integrated with scholarship in particular substantive fields of law. ${ }^{3}$ The causes of this divergence are complex, but among them are surely the American legacy of Legal Realism and the disappearance of equity from the American law school curriculum in the middle of the twentieth century.

* Professor, UCLA School of Law. Email: bray@law.ucla.edu. I am grateful for the comments of two referees, and of Richard Brooks, Andrew Gold, Dan Kelly, Andrew Kull, Douglas Laycock, Marin Levy, Stephen Munzer, Ariel Porat, Eric Posner, Eric Rasmusen, Richard Re, Caprice Roberts, Irit Samet, Rebecca Stone and Peter Turner.

${ }^{1}$ In this article, 'economic analysis' and similar terms are used in their widest and most ecumenical senses: economics in law faculties and economics faculties, first-generation and second-generation law and economics, theoretical economics and experimental economics, 'law and economics' and 'economic analysis of the law', and so on.

2 D Laycock, 'How Remedies Became a Field: A History' (2008) 27 Rev Lit 161.

${ }^{3}$ See, however, Donald Harris, David Campbell, and Roger Halson, Remedies in Contract and Tort, (2nd edn, CUP 2005), dealing with the law and economics of remedies. See also SM Waddams, 'Remedies as a Legal Subject' (1983) 3 OLJS 113 (reviewing Dawson and McLauchlan, The Contractual Remedies Act 1979). There have been steps towards treating remedies for civil wrongs as a general category. See eg A Burrows, Remedies for Torts and Breach of Contract (3rd edn, OUP 2004) vii.

(C) The Author(s) 2017. Published by Oxford University Press. All rights reserved.

For permissions, please e-mail: journals.permissions@oup.com 
This article considers the relationship of these two fields of scholarly inquiry, remedies and economic analysis. It finds a surprising lack of conversation between them. As this article shows, each field bears some of the blame, and each field has much to gain from cooperation on those points where it is possible.

The critique and suggestions offered here are of obvious interest to readers in the fields of remedies and of law and economics, but they also have wider applicability. For readers not ploughing in these fields, the article should be received as a cautionary tale. Misunderstanding is all too possible between law and economics scholars and other legal scholars, and this article shows some of the causes and consequences of that misunderstanding. It is thus useful to scholars whose work is primarily conceptual but who consider drawing on economic and empirical literature.

\section{The Surprising Lack of Conversation}

An observer would expect to find a high degree of affinity between the field of law and economics and that of remedies. For civil litigation, the remedy is the bottom line. In Douglas Laycock's memorable description, a remedy is what 'the court can do for you if you win' and what it 'can do to you if you lose'. ${ }^{4}$ Economic approaches to the law also stress the bottom line. How a person acts today is determined by what he expects the bottom line to be tomorrow. Thus, remedies are a crucial lever for affecting behaviour. They drive deterrence; they set incentives. For law and economics, it is not possession but the remedy that is nine-tenths of the law.

Another reason to expect affinity is that the fields of remedies and economics both cut across substantive areas of law (eg contracts, torts, unjust enrichment, public law). Not everyone is persuaded that remedies should be a distinct field, but for those who are, the rationale for its existence is that there are insights that can be gained only by looking at how a remedy works across substantive areas. $^{5}$ The same tendency to cross substantive lines is characteristic of scholarship in law and economics. It can be found in general treatments such as Economic Analysis of Law by Richard Posner, ${ }^{6}$ an influential judge and prolific scholar long associated with law and economics. The same tendency

\footnotetext{
${ }^{4}$ Laycock (n 2) 165.

5 SL Bray, 'The Supreme Court and the New Equity' (2015) 68 Vand L Rev 997, 1002. It may be worth noting the link between equity and the field of remedies in the United States. At least since Story, writing on equity in the United States has emphasised the equitable remedies, especially the injunction. (Outside of the United States the emphasis has been on other aspects of the equitable inheritance, especially trusts.) When equity fell out of the US law school curriculum about half a century ago, the equitable remedies needed to go somewhere - and the place was the newly emerging field of remedies. There are advantages to thinking of equity and of remedies as subjects of scholarly inquiry. What seems clear is that the replacement of 'equity' with 'remedies' in law schools accelerated the decline in knowledge of equity, even though it remains a critical subject for understanding US law. SL Bray, 'Equity: Notes on the American Reception' in D Klimchuk, I Samet and H Smith (eds), Philosophical Foundations of Equity (OUP forthcoming).

${ }^{6}$ RA Posner, Economic Analysis of Law (9th edn, Wolters Kluwer 2014).
} 
can be found in the distinction between property rules and liability rules, ${ }^{7}$ and also in a recent proposal to unify tort and contract. ${ }^{8}$ Of course, scholars of remedies and scholars of law and economics recognise that different substantive areas have their own goals and priorities; ${ }^{9}$ however, each set of scholars contributes an analysis that is not exclusive to a substantive area.

Despite these reasons for affinity, there is little conversation between remedies and economics. ${ }^{10}$ Consider Guido Calabresi and Douglas Melamed's 'Property Rules, Liability Rules, and Inalienability: One View of the Cathedral' ('The Cathedral'). ${ }^{11}$ It is one of the most-cited law review articles of all time. ${ }^{12}$ Among US scholars, it is without doubt the most influential article ever written on the civil remedies given by courts. However, within the field of remedies, as it is conventionally defined, ${ }^{13}$ 'The Cathedral' has little influence. It is ignored. ${ }^{14}$ It is a champion heavyweight, but within the field of remedies it is a featherweight. ${ }^{15}$ This is not the way economic work has been received in other fields. In the United States, even scholars who do not adopt an economic perspective nevertheless routinely and systematically engage with law and economics arguments. ${ }^{16}$

Or consider the lack of conversation from the other side. Perhaps the most influential book in the field of remedies in the United States is Douglas Laycock's The Death of the Irreparable Injury Rule. ${ }^{17}$ That work has little influence in law and economics scholarship. For example, it has apparently never been cited by Richard Posner. ${ }^{18}$ Nor has Laycock's book ever been cited in the Fournal of Law and Economics, the Fournal of Legal Studies or the American

${ }^{7}$ G Calabresi and AD Melamed, 'Property Rules, Liability Rules, and Inalienability: One View of the Cathedral' (1972) 85 Harv L Rev 1089.

8 eg RD Cooter and A Porat, Getting Incentives Right: Improving Torts, Contracts, and Restitution (Princeton UP 2014).

9 eg A Porat (ed), The Economics of Remedies (Edward Elgar 2012) ix; D Partlett, 'Remedies in a Wide-Angle Lens: Observations on Remedial Consilience' (2014) 63 Emory L J 2053, 2064.

${ }_{10}$ The point is not about economic analysis of remedies within a substantive field (eg contracts), but about the interaction of economic analysis and the cross-cutting field of remedies. For further discussion, see section 3.

${ }^{11}$ Calabresi and Melamed (n 7).

12 FR Shapiro and M Pearse, 'The Most-Cited Law Review Articles of All Time' (2012) 110 Mich L Rev $1483,1489$.

${ }^{13}$ Laycock (n 2).

14 There are exceptions, such as the critiques offered by Laycock and Rendleman, see n 14, as well as E Sherwin, 'Introduction: Property Rules as Remedies' (1997) 106 Yale LJ 2083.

${ }^{15}$ And a featherweight that has been knocked out several times. See D Laycock, 'The Neglected Defense of Undue Hardship (and the Doctrinal Train Wreck in Boomer v. Atlantic Cement)' (2012) 4 JETL 1; D Rendleman, 'Rejecting Property Rules-Liability Rules for Boomer's Nuisance Remedy: The Last Tour You Need of Calabresi and Melamed's Cathedral' (2013) SSRN Working Paper.

16 eg GC Keating, 'The Priority of Respect over Repair' (2012) 18 LEG 293; SV Shiffrin, 'The Divergence of Contract and Promise' (2007) 120 Harv L Rev 708, 710; JL Coleman, 'Some Reflections on Richard Brooks's "Efficient Performance Hypothesis"” (2007) 116 Yale LJ Pocket Part 416.

${ }_{17}$ D Laycock, The Death of the Irreparable Injury Rule (OUP 1991), reviewed in CEF Rickett (1991) 50 CLJ 536; D Laycock, 'The Death of the Irreparable Injury Rule' (1990) 103 Harv L Rev 687.

${ }^{18}$ Nor has it ever been cited in a law review article by most of the leading law and economics scholars in the United States. There are exceptions, eg I Ayres and $\mathrm{K}$ Madison, 'Threatening Inefficient Performance of Injunctions and Contracts' (1999) 148 U Pa L Rev 45, 65; D Markovits and A Schwartz, 'The Myth of Efficient Breach: New Defenses of the Expectation Interest' (2011) 97 Va L Rev 1939, 1986-7 fns 81 and 84; HE Smith, 'On the Economy of Concepts in Property' (2012) 160 U Pa L Rev 2097, 2125 fn 106. 
Law and Economics Review. In his work, Laycock criticised US courts because they would inquire into whether legal remedies were adequate before granting an equitable remedy. When doing so, US courts typically use the phrases 'adequate remedy at law' and 'irreparable injury'. ${ }^{19}$ However, 'adequate remedy at law' has rarely appeared in the volumes of these journals ${ }^{20}$ and 'irreparable injury' has appeared only once: in an article published almost 40 years ago, the phrase appears in a quotation in a footnote. ${ }^{21}$ For better or for worse, unless one discusses the adequacy of legal remedies, there is not much one can say about the precise contours of the doctrine regarding equitable remedies, including injunctions and specific performance. ${ }^{22}$

This point can be overstated. The remedies casebooks used in the United States do occasionally refer to economic analysis. Scholars writing in law and economics, whether in the United States or England, do address damages and injunctions. In scholarship that is self-consciously within the field of remedies, however, there is relatively little interaction with economic work, especially work that is recent. And in economic scholarship on remedies, there is relatively little interaction with scholarship from the field of remedies. Why?

\section{Law and Economics}

Let us begin with economics. Four sources are briefly considered here for what they say about remedies: (i) Guido Calabresi and Douglas Melamed's 'The Cathedral', ${ }^{23}$ (ii) Robert Cooter's 'Prices and Sanctions'; ${ }^{24}$ (iii) William Landes and Richard Posner's 'The Economics of Anticipatory Adjudication'; ${ }^{25}$ and (iii) a

\footnotetext{
19 Similar terms are used in English law, eg Lawrence v Fen Tigers Ltd [2014] AC 822, 863 (Lord Sumption) ('The ordinary principle is that the court does not grant an injunction in a case where there is an adequate legal remedy'); Co-operative Insurance Society Ltd v Argyll Stores (Holdings) Ltd [1998] AC 1, 11 (Lord Hoffmann) ('This is the basis of the general principle that specific performance will not be ordered when damages are an adequate remedy').

${ }^{20}$ The exact phrase appears in three articles in these journals. In only one, 20 years ago, was the doctrine a topic of considerable discussion. PG Mahoney, 'Contract Remedies and Options Pricing' (1995) 24 JLS 139, 139, 154-6. The phrase was used in passing in PD Carrington, 'Adjudication as a Private Good: A Comment' (1979) 8 JLS 303, 310, and inaptly in JO Lanjouw and J Lerner, 'Tilting the Table? The Use of Preliminary Injunctions' (2001) 44 JLE 573, 577. A similar phrase was used in passing in R Craswell, 'Insecurity, Repudiation, and Cure' (1990) 19 JLS 399, 426 and fn 51. Similar terminology was used in O Bar-Gill and O Ben-Shahar, 'The Law of Duress and the Economics of Credible Threats' (2004) 33 JLS 391, though the question considered was not the choice of remedies but rather the enforcement of a contract modification.

${ }^{21}$ GP O’Driscoll, Jr, 'The American Express Case: Public Good or Monopoly?' (1976) 19 JLE 163, 164 fn 3. It is true that scholars writing in law and economics have discussed the doctrine outside the pages of these journals.

${ }^{22}$ This is not to say that it is difficult for a plaintiff to show there is 'no adequate remedy at law'. JD Heydon, MJ Leeming and PG Turner, Meagher, Gummow \& Lehane's Equity: Doctrines \& Remedies (5th edn, LexisNexis Butterworths 2015) \$21-040, 706-7; Laycock (n 17). Rather, this principle is used by courts as a shorthand for a variety of considerations that go into the decision to grant or deny an equitable remedy. E Sherwin and SL Bray, Ames, Chafee, and Re on Remedies (2nd edn, Foundation forthcoming).

${ }^{23}$ Calabresi and Melamed (n 7).

${ }^{24}$ R Cooter, 'Prices and Sanctions' (1984) 84 Colum L Rev 1523. An updated version appears in Cooter and Porat (n 8) 17-31.

${ }^{25}$ WM Landes and RA Posner, 'The Economics of Anticipatory Adjudication' (1994) 23 JLS 683.
} 
recently published book by Robert Cooter and Ariel Porat, Getting Incentives Right: Improving Torts, Contracts, and Restitution. ${ }^{26}$ Although these are obviously selections, they are not arbitrary. The first two are foundational for many economic analyses of the law. The third is the leading - indeed, the onlyeconomic model of the declaration. The fourth is recent and likely to be influential. These are excellent, even brilliant, pieces of scholarship-yet, it will be argued, they illustrate how law and economics scholars contribute to the lack of conversation with the field of remedies. Then turnabout will be fair play.

'The Cathedral' introduced the concept of protecting entitlements with property rules and liability rules. ${ }^{27}$ There is much to criticise in how 'The Cathedral' describes remedies. ${ }^{28}$ It would not, of course, be fair to criticise it for mere lack of detail: Calabresi and Melamed were offering a model for thinking about remedies, and models necessarily abstract out details in order to get at more essential points. Rather, the criticism is that the image of the injunction in 'The Cathedral' is almost exactly the inverse of how the injunction actually operates.

Calabresi and Melamed present the injunction as an exclusive means of protecting some entitlements. ${ }^{29}$ It is not. There is no such thing as an entitlement protected by an injunction. When an entitlement is taken (or a right is violated-I am not quibbling about the terminology), an array of different remedies will nearly always be possible. ${ }^{30}$ For example, when courts are asked to give an injunction to prevent a multiplicity of actions or to prevent a violation of the plaintiff's rights, they almost invariably face a decision about whether the plaintiff should receive an equitable remedy or be left to a legal one. ${ }^{31}$ A violation of a right may be remedied by an injunction, but there is discretion in that choice. If the court does give an injunction and it is violated, it may then be swapped for an award of money (ie compensatory civil contempt). ${ }^{32}$

\footnotetext{
${ }^{26}$ Cooter and Porat (n 8).

${ }^{27}$ Calabresi and Melamed (n 7) 1092: 'An entitlement is protected by a property rule to the extent that someone who wishes to remove the entitlement from its holder must buy it from him in a voluntary transaction in which the value of the entitlement is agreed upon by the seller... Whenever someone may destroy the initial entitlement if he is willing to pay an objectively determined value for it, an entitlement is protected by a liability rule.' The category of alienability rules is less relevant for remedies.

28 The criticisms that follow are directed toward 'The Cathedral' itself. The vast subsequent literature sometimes corrects, and sometimes doubles down, on these mistakes. The reception of 'The Cathedral' is beyond the scope of this article.

${ }^{29}$ All of Calabresi and Melamed's examples presuppose that an entitlement is protected by a property rule or a liability rule but not both, and though they recognise questions of degree, they describe as disjunctive the choice a society has between different modes of protecting entitlements. This portrayal is not merely a matter of property rules and liability rules as ideal types, as can be seen in how Calabresi and Melamed apply that disjunctive choice to actual legal entitlements.

${ }^{30}$ cf M Polinsky, 'Resolving Nuisance Disputes: The Simple Economics of Injunctive and Damage Remedies' (1980) 32 Stan L Rev 1075, 1086-8 (noting that an entitlement may be given a mix of liability- and propertyrule protection).

31 Heydon, Leeming and Turner (n 22) \$21-025-\$21-040, 702-7.

32 Rendleman (n 15) `27; see also JE Penner, The Idea of Property in Law (Clarendon Press 1997) 67 ('Any scheme of individuation which intends to equate normative guidance with motivational effect must, in actuality,
} 
Calabresi and Melamed present the injunction as a remedy that is given automatically, as a matter of right. A rule is chosen, the remedy follows. ${ }^{33}$ But it is blackletter law that injunctions are not given automatically. ${ }^{34}$ 'Because the injunction is a discretionary remedy, the court may refuse the injunction even if the plaintiff establishes an infringement, or threatened infringement, of his or her rights. 35

Calabresi and Melamed present the scope of the injunction as essentially fixed by the scope of the underlying entitlement. There is no daylight between the entitlement and the injunction. ${ }^{36}$ It is, however, blackletter law that injunctions are not merely a restatement of the scope of the underlying entitlement; rather, an injunction may (and in US law should) say either more or less than 'obey the law'. 37

Calabresi and Melamed describe the injunction as the remedy that involves less state intervention. They characterise property-rule protection as 'the form of entitlement which gives rise to the least amount of state intervention: once the original entitlement is decided upon, the state does not try to decide its value'. ${ }^{38}$ Calabresi and Melamed offer an exceedingly narrow definition of 'state intervention' in a footnote, ${ }^{39}$ but for readers who neglect the idiosyncratic definition, the statement is sure to mislead. Injunctions are often difficult to enforce. This is particularly likely to be true of mandatory injunctions. And

be much more fine-grained than Calabresi and Melamed's, for one presumes that different persons will be differently motivated by different stages of the remedial sequence').

33 eg Calabresi and Melamed (n 7) $1118,1121$.

34 eg Heydon, Leeming, and Turner (n 22) \$21-195-\$21-225, 738-45 (injunctions restraining breaches of contract); Monsanto Co v Geertson Seed Farms, 561 US 139, 156-8 (2010); Winter v Natural Resources Defense Council, 555 US 7, 32; eBay Inc v MercExchange, LLC, 547 US 388, 395 (2006) (Chief Justice Roberts, concurring); see also Salazar v Buono, 559 US 700, 714 (2010) (plurality opinion) (equitable relief generally); JNE Varuhas and PG Turner, 'Injunctions, Undertakings in Damages and the Public-Private Divide' (2014) 130 LQR 33, 36 (noting that a public authority enforcing the law may choose whether to seek an injunction). cf Sherwin (n 14) 2086 ('Because the identity of the remedy is uncertain until a dispute has been adjudicated, property rules and liability rules cannot serve as incentives before that time').

${ }^{35}$ N Witzleb, “Equity Does Not Act in Vain”: An Analysis of Futility Arguments in Claims for Injunctions' (2010) 32 Sydney L Rev 503, 505; see also HJ Friendly, 'Indiscretion about Discretion' (1982) 31 Emory LJ $747,778 \mathrm{fn} 116$. There are, of course, principles in equity, and many decisions about equitable relief are predictable. As Henry McClintock said, 'The statement that equitable relief cannot be demanded as a matter of right, but is given in the discretion of the court, is still true with the qualification that the discretion is not the mere personal discretion of the chancellor or judge, but is a judicial discretion, which means that the judge consults precedents to find the principles, as distinguished from strict rules, which are applicable to a given situation, and then determines, from all the facts in the case, what relief will best give effect to the various principles involved.' HL McClintock, Handbook of the Principles of Equity (2nd edn, West 1948) 51-2.

36 eg Calabresi and Melamed ( $\mathrm{n}$ 7) 1116 ('The first is an entitlement to be free from pollution and is protected by a property rule')

37 eg CA Wright and others, Federal Practice and Procedure (3rd edn, West 2016) \2955 and fn 25 (collecting cases about obey-the-law injunctions); see also JM Golden, 'Injunctions As More (Or Less) Than "Off Switches”: Patent-Infringement Injunctions' Scope’ (2012) 90 Tex L Rev 1399. As Golden notes, this requirement of US law is not always followed.

38 Calabresi and Melamed (n 7) 1092.

39 The qualifying footnote says, in part: 'A property rule requires less state intervention only in the sense that intervention is needed to decide upon and enforce the initial entitlement but not for the separate problem of determining the value of the entitlement.' Calabresi and Melamed (n 7) $1092 \mathrm{fn} 7$. 
when enforcement is needed, an injunction will require state intervention, especially if there are contempt proceedings. ${ }^{40}$

Calabresi and Melamed seem to regard the injunction as difficult to amend. They treat 'the market place' as the means by which initial entitlements are altered. ${ }^{41}$ Yet the blackletter law is that many so-called 'permanent' injunctions are not really permanent, since they are subject to subsequent modification and dissolution. ${ }^{42}$

Finally, where Calabresi and Melamed do identify some features of actual injunction practice, such as compensated injunctions (relying on Spur Industries, Inc v Del $\mathrm{E}$ Webb Development $\mathrm{Co}^{43}$ ) and the balancing of hardships for a permanent injunction (relying on Boomer $v$ Atlantic Cement $\mathrm{Co}^{44}$ ), they tend to misunderstand them. They treat these cases as remarkable innovations.

To the contrary, Boomer was a garden-variety exercise of equitable discretion. ${ }^{45}$ As Justice Brandeis of the US Supreme Court said half a century earlier,

Instances are numerous where protection to property by way of injunction has been refused solely on the ground that serious public inconvenience would result from restraining the act complained of. Such, for example, was the case where a neighbouring landowner sought to restrain a smelter from polluting the air, but that relief, if granted, would have necessitated shutting down the plant, and this would have destroyed the business and impaired the means of livelihood of a large community. ${ }^{46}$

Spur Industries, with its compensated injunction for ending a nuisance, was somewhat novel. If we look past form to substance, however, its remedy resembled a number of English and American cases in which a court conditioned equitable relief upon the plaintiff making some kind of payment to the defendant. ${ }^{47}$ The general principle is stated this way by the leading

\footnotetext{
${ }^{40} \mathrm{cf}$ Rendleman (n 15) ${ }^{\star} 27$ ('Calabresi and Melamed's ... view that an injunction is inviolable and selfenforcing, is an incorrect statement about an injunction as a remedy in actual disputes').

41 Calabresi and Melamed (n 7) 1119.

42 United States v Swift \& Co, 286 US 106, 114 (1932) (Justice Cardozo) ('A continuing decree of injunction directed to events to come is subject always to adaptation as events may shape the need'). See generally TS Jost, 'From Swift to Stotts and Beyond: Modification of Injunctions in the Federal Courts' (1986) 64 Tex L Rev 1101 .

${ }^{43} 108$ Ariz 178 (1972). In Spur Industries, after a huge retirement community had been located next to a preexisting malodorous feedlot for cattle and the developer had sued the feedlot for nuisance, the court (i) enjoined the operation of the feedlot while also (ii) requiring the developer to indemnify the feedlot owner for reasonable costs of moving or shutting down.

4426 NY2d 219 (1970). In Boomer, upon proof that the defendant factory committed a nuisance against neighbouring landowners, the court gave damages (more precisely, awarded an injunction that would be vacated upon the payment of damages by the defendant) because of the economic consequences of shutting down the factory with an injunction.

${ }^{45}$ Laycock (n 15); Rendleman (n 15). As Laycock notes, the same misunderstanding of Boomer is found in other scholarship: 'The current edition of Judge Posner's textbook refers to "the court's novel remedial approach" in Boomer, suggesting that he has been misled by the Boomer opinion and may be unfamiliar with the large body of earlier cases.' Laycock (n 15) 20.

${ }^{46}$ Truax $v$ Corrigan, 257 US 312, 375 (1921) (Justice Brandeis, dissenting). For the principle that the public interest may be considered when a court exercises its discretion regarding whether to enjoin a nuisance, see Lawrence v Fen Tigers Ltd [2014] AC 822, 856, (Lord Neuberger).

${ }^{47}$ For US examples, see High Knob, Inc v Allen, 205 Va 503 (1964) (conditioning injunction on plaintiff's paying a share of defendant's maintenance costs); Brehm v Richards, 152 Md 126 (Md Ct App 1927) (conditioning injunction on plaintiff's paying defendant the value of the improvements defendant had made); Lindsey v Clark, 193
} 
equity treatise: 'If the decree is to be final, equity may impose any condition on the plaintiff that will protect the legal or equitable rights of the defendant as the price of granting relief. ${ }^{\text {, }} 8$ Indeed, 'Those who seek equity must do equity' is a maxim that 'serves to point to a very important distinction between equity and the law, namely the ability of equity to give conditional relief'. 49

'The Cathedral' is not unique in this regard. Consider the distinction that Robert Cooter develops in 'Prices and Sanctions'.50 A price is 'money extracted for doing what is permitted'. ${ }^{51}$ A sanction is 'a detriment imposed for doing what is forbidden', and it is 'essential that the sanction be large enough so that [a person's] private costs are minimized by conforming to the legal standard'.52 Cooter's distinction between prices and sanctions elegantly captures how legal rules should be shaped by the kind of knowledge officials have. $^{53}$

There are, however, two problems with deploying Cooter's concept of prices and sanctions in remedies. First, in civil remedies (at the very least, outside of contract law), there are almost no prices. Secondly, although there are sanctions, they are rarely large enough to achieve the effect Cooter describes. Those who try to 'pay their price and take their choice' will find that various doctrines heighten the remedy because of their wilfulness. Only rarely will the remedy truly rise to the level of an effective 'sanction' in Cooter's terminology. Even in the common law jurisdiction most attached to punitive damages, the United States, such damages are subject to reduction when they become excessive. ${ }^{54}$ Liquidated damages are sometimes denied because they exceed actual injury. ${ }^{55}$ Actual injury influences the amount a court awards in statutory

Va 522 (1952) (conditioning equitable relief on plaintiff's transfer of an easement to the defendant); White v Massee, 202 Iowa 1304 (1927) (conditioning injunction on plaintiff's paying the rental costs of her elderly father, who was not a party but was substantially aligned with defendant). A historic analogue is Allen's Case (c 1610), offering the defendant an election 'whether he would keep the land and pay the money or depart with the land and receive his money'. Reprinted in WH Bryson (ed), Cases Concerning Equity and the Courts of Equity, 15501660, vol 1 (Selden Society 2001) 387, 389, no 174 .

${ }^{48}$ Heydon, Leeming and Turner (n 22) \$3-050-\$3-070, 74-7 (citing examples).

49 Heydon, Leeming and Turner (n 22) $\$ 3-050,74-5$. In the United States as well, such conditions are often associated with the maxim that 'he who seeks equity must do equity'. SW Symons, Pomeroy's Equity Furisprudence (5th edn, Bancroft-Whitney 1941) \$393d, 83-4.

${ }^{50}$ Cooter (n 24).

51 Cooter (n 24) 1524.

52 Cooter (n 24) 1524, 1527.

53 For updated discussion, see Cooter and Porat (n 8) 27-30.

${ }^{54}$ On remittitur for punitive damages, see CP Murphy, 'Judgment as a Matter of Law on Punitive Damages' (2000) 75 Tul L Rev 459; Brad Snyder, 'Protecting the Media from Excessive Damages: The NineteenthCentury Origins of Remittitur and Its Modern Application in Food Lion' (2000) 24 Vt L Rev 299. Although Cooter gives punitive damages as an example of a sanction, Cooter (n 24) 1543-4, in Cooter and Porat's updated discussion there is only a passing mention of punitive damages, Cooter and Porat (n 8) $23 \mathrm{fn} 6$. Cooter does not discuss remittitur. The US Supreme Court's line of cases restricting punitive damages under the Due Process Clause began two years after 'Prices and Sanctions' was published.

${ }^{55}$ D Laycock, Modern American Remedies (4th edn, Aspen 2010) 77-8. Thus, courts sometimes say that 'contractual terms providing for the payment of a sum disproportionate to the amount of actual damages exact a penalty and are unenforceable'. Leasing Service Corp v fustice, 673 F2d 70, 73 (2nd Cir 1982). 
damages. ${ }^{56}$ Equitable remedies are not supposed to punish. ${ }^{57}$ Moreover, someone who violates an injunction may wind up having to pay a compensatory civil contempt award that looks awfully like damages. ${ }^{58}$

Now one might say that property rules and liability rules, and prices and sanctions, are stylised concepts that are intentionally overdrawn. However, even when there are explicit doctrinal assertions in the economic literature on remedies, there is sometimes what could be called, with charity, room for doubt. For example, William Landes and Richard Posner offer a model of anticipatory judicial decision making, and one of the predictions of the model is that declarations ('declaratory judgments' in US parlance) will be given more claim-preclusive effect than other judgments. ${ }^{59}$ The law, say Landes and Posner, coincides with the prediction of the model. But the American law that Landes and Posner purport to describe is very nearly the reverse: as long as the only remedy a US plaintiff seeks is a declaration, the suit does not have claimpreclusive effect. ${ }^{60}$ That is, the plaintiff is not precluded from subsequently bringing a suit for other relief on the same set of facts. There is, however, issue preclusion (ie whatever is actually decided in the case is settled for future litigation) - even though Landes and Posner expressly say that issue preclusion is not included in their model. ${ }^{61}$ Whether the law is wrong or the model is wrong, or there is some possibility of rapprochement, these are good questions. ${ }^{62}$ Yet they are questions that Landes and Posner could address only after accurately stating what the law is.

A final example: In their recent book, Getting Incentives Right, ${ }^{63}$ Robert Cooter and Ariel Porat offer a number of compelling analyses of questions in tort, contract and unjust enrichment. ${ }^{64}$ One of their proposals is that damage awards should be reduced by the amount of certain 'nonlegal sanctions' suffered by the defendant. ${ }^{65}$ The analysis is more subtle than can be

56 eg Capitol Records Inc v Thomas-Rasset, 680 F Supp 2d 1045 (D Minn 2010).

${ }^{57}$ SL Bray, 'Punitive Damages against Trustees?' in DG Smith and AS Gold (eds), Research Handbook on Fiduciary Law (Edward Elgar forthcoming).

58 DB Dobbs, Law of Remedies: Damages-Equity-Restitution, vol 1 (2nd edn, West 1993) $\$ 2.8(2), 194$ and fn 18.

${ }^{59}$ Landes and Posner (n 25) 700-1 (' $[\mathrm{A}] \mathrm{n}$ important feature of anticipatory judgments is that they can be pleaded as res judicata in a subsequent case').

${ }^{60}$ SL Bray, 'Preventive Adjudication' (2010) 77 U Chi L Rev 1275, 1293 and fn 76; 1320 fn 186; Mycogen Corp v Monsanto Co, $28 \mathrm{Cal}$ 4th 888 (2002).

${ }^{61}$ Landes and Posner (n 25) 700 (referring to '[t]he doctrine of collateral estoppel' as one 'we do not discuss in this article'). It could be that Landes and Posner are saying 'res judicata' (ie claim preclusion or cause of action estoppel) when they mean 'collateral estoppel' (ie issue preclusion or issue estoppel) and vice versa. I am not sure if that explanation would make the mistake better or worse.

${ }^{62}$ See G Calabresi, 'Of Law and Economics and Economic Analysis of Law: The Role of the Lawyer' in The Future of Law and Economics: Essays in Reform and Recollection (Yale 2016).

63 Cooter and Porat (n 8).

${ }^{64}$ Cooter and Porat use the term 'restitution', but I reserve that term for remedies and will describe the claim as sounding in 'unjust enrichment'.

${ }^{65}$ This chapter builds on an earlier article: R Cooter and A Porat, 'Should Courts Deduct Nonlegal Sanctions from Damages?' (2001) 30 JLS 401. For a critique, see EM Iacobucci, 'On the Interaction between Legal and Reputational Sanctions' (2014) 43 JLS 189. 
summarised here, and there are important qualifications in their account, but one example will give its flavour:

Example 4: Sharp Dealing II. A company aggressively interprets a contract with a supplier and eventually breaches. When the supplier sues, the court finds that damages of $\$ 100$ will perfectly compensate the victim for breach. Although consumers who buy from the company are not at risk, the news of the court's finding makes some of them angry and they boycott the company, which causes it to lose $\$ 25$ in profits and its competitors to gain $\$ 25$ in profits. Should the court award damages of $\$ 100$ or $\$ 75$ ?

To find the answer, apply the general principle that efficient deterrence requires the court to set damages equal to the victim's harm (\$100) minus the benefit to others (\$25). Thus, the court should ideally award net damages, which equal $\$ 75$. Awarding more than $\$ 75$ in damages would overdeter by prompting excessive precaution in contracts. ${ }^{66}$

Now this conclusion is not the law, but that is less interesting than the premise from which it proceeds. That premise is plainly stated by Cooter and Porat: the remedies awarded by courts should be set so as to minimise social costs. ${ }^{67}$ Working from that premise, the argument is fairly strong (and, as noted, more subtle than the passage just quoted). ${ }^{68}$ That premise, though, is entirely different from the view of many scholars of remedies: the primary goal of remedies, ${ }^{69}$ though certainly not the only goal, ${ }^{70}$ is achieving the plaintiff's rightful position. A scholar who starts with the goal of the rightful position will not deduct from the plaintiff's recovery whatever the defendant's competitors happened to make. Those transactions between non-parties are no part of the plaintiff's rightful position; they do not affect the recovery.

To summarise: 'The Cathedral' is brilliant but wrong in what it says about the injunction; 'Prices and Sanctions' is brilliant but largely inapplicable to remedies; 'The Economics of Anticipatory Adjudication' is brilliant but misstates a basic point of blackletter law; and Getting Incentives Right is brilliant but proceeds from a premise wholly different from that of most remedies scholars. This tour was both brief and selective. There are plenty of exceptions. For example, there is sophisticated and insightful work on the offsetting-

${ }^{66}$ Cooter and Porat (n 8) 193 (footnote omitted).

${ }^{67}$ Cooter and Porat (n 8) 187.

${ }^{68}$ One line of critique is that setting damages lower than the harm distorts the decisions of the plaintiff about which activities to engage in. cf AM Polinsky and S Shavell, 'Punitive Damages: An Economic Analysis' (1998) 111 Harv L Rev 870, 881-2 (making this point about defendants).

69 See Laycock (n 55) 14-15; TA Thomas, 'Congress' Section 5 Power and Remedial Rights' (2001) 34 UC Davis L Rev 673, 725; Waddams (n 3) 115; see also Chronister Oil Co v Unocal Ref and Mktg, 34 F 3d 462, 464 (7th Cir 1994) (Chief Judge Posner).

${ }^{70}$ See Burrows (n 3) 9-11; E Sherwin, 'Compensation and Revenge' (2003) 40 San Diego L Rev 1387, 1388. Emphasis on the defendant's position, and not merely that of the plaintiff, is a traditional characteristic of equity. See R Hedlund, 'The Theological Foundations of Equity's Conscience' (2015) 4 Oxford Journal of Law \& Religion 119, 124-6. 
benefits doctrine by Ariel Porat and Eric Posner ${ }^{71}$ and on pain-and-suffering damages by Ronen Avraham. ${ }^{72}$ As Douglas Laycock has noted, Richard Epstein, Thomas Merrill and Henry Smith have all shown an adroit grasp of the undue-hardship defence. ${ }^{73}$ Smith has skilfully analysed equity from an economic standpoint. ${ }^{74}$ Mitchell Polinsky and Steven Shavell have offered a model for the socially optimal form of punitive damages, while carefully noting how the law diverges from the model. ${ }^{75}$ Anthony Duggan has combined a close reading of Harris $v$ Digital Pulse Pty $L t d^{76}$ and other cases with an economic argument for punitive damages. ${ }^{77}$

One might reasonably object that the preceding analysis contains a major mistake: it leaves out the large bodies of scholarship, sophisticated in both doctrinal grasp and economic analysis, that concern the remedies given in specific substantive areas, such as contracts or patent law. As a factual matter, this objection is correct. Think, for example, of the work by Richard Brooks and Alexander Stremitzer on rescission as a remedy in contract. ${ }^{78}$ More generally, it is certainly the case that in economic scholarship on contract law, other leading figures have also shown deep knowledge and insight about contract remedies. ${ }^{79}$ In patent law, one could cite the work of Thomas Cotter, John Golden and Mark Lemley, among others. ${ }^{80}$ There are multiple examples

${ }^{71}$ A Porat and E Posner, 'Offsetting Benefits' (2014) 100 Va L Rev 1165.

${ }^{72}$ R Avraham, 'Putting a Price on Pain-and-Suffering Damages: A Critique of the Current Approaches and a Preliminary Proposal for Change' (2006) 100 Northwestern University Law Review 87.

${ }^{73}$ Laycock (n 15) 20-1. Among the sources Laycock cites are RA Epstein, 'A Clear View of the Cathedral: The Dominance of Property Rules' (1997) 106 Yale LJ 2091, 2101-2; TW Merrill, 'Golden Rules for Transboundary Pollution' (1997) 46 Duke LJ 931, 943-4, 1001; HE Smith, 'Institutions and Indirectness in Intellectual Property' (2009) 157 U Pa L Rev 2083, 2125-32.

${ }^{74} \mathrm{H}$ Smith, 'Fusing the Equitable Function in Private Law' in K Barker, K Fairweather and $\mathrm{R}$ Grantham (eds), Private Law in the 21st Century (Hart Publishing 2017) 173-95; H Smith, 'An Economic Analysis of Law Versus Equity' (2010) working paper www.law.yale.edu/documents/pdf/LEO/HSmith_LawVersusEquity7.pdf

${ }^{75}$ Polinsky and Shavell (n 68). For a close reading of a punitive damages case, see S Shavell, 'On the Proper Magnitude of Punitive Damages: Mathias v Accor Economy Lodging, Inc' (2007) 120 Harv L Rev 1223.

76 (2003) 56 NSWLR 298.

77 A Duggan, 'Exemplary Damages in Equity: A Law and Economics Perspective' (2006) 26 OJLS 303. I am more skeptical of punitive damages against trustees. Bray (n 57).

78 eg RRW Brooks and A Stremitzer, 'Remedies On and Off Contract' (2011) 120 Yale LJ 690; see also RRW Brooks and A Stremitzer, 'On and Off Contract Remedies Inducing Cooperative Investments' (2012) 14 American Law and Economics Review 488. Even so, note that Brooks and Stremitzer make no distinction between rescission at law and equitable rescission, though that distinction endures in many jurisdictions. SL Bray, 'The System of Equitable Remedies' (2016) 63 UCLA L Rev 530, 555-6; M Leeming, 'Overlapping Claims at Common Law and in Equity-An Embarrassment of Riches?' J Equity (forthcoming).

${ }^{79}$ eg O Ben-Shahar and L Bernstein, 'The Secrecy Interest in Contract Law' (2000) 109 Yale LJ 1885; JE Calfee and R Craswell, 'Some Effects of Uncertainty on Compliance with Legal Standards' (1984) 70 Va L Rev 965; R Craswell, 'Deterrence and Damages: The Multiplier Principle and Its Alternatives' (1999) 97 Mich L Rev 2185; AS Edlin and A Schwartz, 'Optimal Penalties in Contracts' (2003) 78 Chi-Kent L Rev 33; VP Goldberg, 'The New-Business Rule and Compensation for Lost Profits' (2016) 1 Criterion Journal on Innovation 341; AW Katz, 'Remedies for Breach of Contract under the CISG' (2005) 25 International Review of Law \& Economics 378; A Porat, 'A Comparative Fault Defense in Contract Law' (2009) 107 Mich L Rev 1397; RE Scott, 'The Case for Market Damages: Revisiting the Lost Profits Puzzle' (1990) 57 U Chi L Rev 1155; TS Ulen, 'The Efficiency of Specific Performance: Toward a Unified Theory of Contract Remedies' (1984) 83 Mich L Rev 341.

${ }^{80}$ eg TF Cotter, Comparative Patent Remedies: A Legal and Economic Analysis (OUP 2013); JM Golden, 'Principles for Patent Remedies' (2010) 88 Tex L Rev 505; MA Lemley and C Shapiro, 'Patent Holdup and Royalty Stacking' (2007) 85 Tex L Rev 1991. 
from other doctrinal fields, including antitrust, torts, property, civil procedure and fiduciary law. ${ }^{81}$

If there is not much interaction between the fields of remedies and economics (ie at that level of generality) but there is substantial interaction between doctrinal and economic analysis within substantive areas, is there really a problem? There is, and the problem is as simple as the reason for remedies being considered as a discrete field. If the economically informed, doctrinally sensitive work on remedies occurs in contract law, patent law and so on but is not cross-cutting, then there will be duplicated work and missed insights. ${ }^{82}$ This point helps us better understand the puzzle: it is at the level of crosssubstantive work on remedies that there is a surprising lack of conversation with economics. It is also at this level that even these leading works of law and economics scholarship contribute to the lack of discussion.

\section{Remedies}

Now to gore another ox. Remedies scholars have, on the whole, made surprisingly little use of economic concepts. Classic articles that are foundational for later economic treatments of remedies, such as 'The Cathedral' and 'Prices and Sanctions', are rarely cited, much less engaged in detail. In the field of remedies, citations to economic journals are even more rare. That goes not only for Econometrica and American Economic Review, but also for journals that tend to be less mathematically imposing and more immediately concerned with law, such as the Fournal of Law and Economics and the Fournal of Legal Studies. Such journals do include articles that pertain to remedies. For example, recent volumes of the fournal of Legal Studies included articles about high-low agreements (which are made before trial to narrow the range of the plaintiff's recovery), ${ }^{83}$ caps on non-economic damages in medical malpractice cases $^{84}$ and the relationship between legal and reputational sanctions. ${ }^{85}$ Even the empirical findings of scholars in law and economics that are published in law reviews tend to receive little attention from remedies scholars. ${ }^{86}$

${ }^{81}$ It is no accident that most of the articles collected in The Economics of Remedies (n 9), apart from those concerned with property rules and liability rules, are about remedies in a single substantive field.

${ }^{82}$ Bray (n 5) 1002. On reasons for the emergence of remedies as a field in the United States, see n 5. 699.

83 JJ Prescott, KE Spier and A Yoon, 'Trial and Settlement: A Study of High-Low Agreements' (2014) 57 JLS

${ }^{84}$ EMJ Lieber, 'Medical Malpractice Reform, the Supply of Physicians, and Adverse Selection' (2014) 57 JLS 501 .

${ }_{85}$ Iacobucci (n 65). Or, to take another example, an article in the American Law and Economics Review shows that bilateral cooperative investments can be ensured through contract design under an expectation-damages regime-implicitly undermining a rationale for liquidated damages. D Göller, 'Expectation Damages and Bilateral Cooperative Investments' (2014) 16 American Law and Economics Review 473. A little further back, the fournal of Economic Perspectives published a symposium on contingent valuation. Volume 26, number 4 (Fall 2012).

${ }^{86}$ For example, it seems that $\mathrm{T}$ Wilkinson-Ryan, 'Do Liquidated Damages Encourage Breach? A Psychological Experiment' (2010) 108 Mich L Rev 63, has never been cited in a law review article by a remedies scholar. It has been cited in two remedies casebooks: Laycock (n 55) 80; Sherwin and Bray (n 22). 
Where economic analysis has been introduced in remedies scholarship, it tends to resemble a stock character-often a villain, usually a grizzled one, like that old gangster Efficient Breach. ${ }^{87}$ But it does not have to be this way. Economic analysis is richer than this, and the economists have moved on. ${ }^{88}$ There are many other economic literatures that could be brought to bear in scholarship on the law of remedies, both theoretical and experimental. Consider two examples: ${ }^{89}$

1. There is a paradox at the heart of equitable remedies. The equitable remedies are the ones that are most richly equipped with devices for managing the parties: contempt, modification and dissolution, masters and receivers, and placement of conditions on the plaintiff or defendant. ${ }^{90}$ Yet these are the very same remedies that courts often decline to give on the ground that they would require too much management of the parties. Thus, the equitable remedies are the most apt for managing the parties, but the need to manage the parties is itself a reason not to give these remedies.

One way to make progress on this paradox might be game theory, modelling the interactive decision making of the plaintiff, defendant and court. These three actors have diverging incentives. ${ }^{91}$ Each also has different information: the plaintiff may know more about the experience of the violation and the defendant may know more about the possibilities for compliance, while the court may be the only repeat player. The defendant may want the injunction to fail, so it will be modified or dissolved. ${ }^{92}$ The plaintiff may want the injunction to succeed or he may want it to fail, to add the threat of contempt to the settlement negotiations. The court may just want the case to go away. These

\footnotetext{
87 One might think of Arthur Leff's description of Richard Posner's classic textbook Economic Analysis of Law as a picaresque novel with Economic Analysis as its eponymous hero. AA Leff, 'Economic Analysis of Law: Some Realism about Nominalism' (1974) 60 Va L Rev 451, 451-2. Laycock's article on undue hardship is generally nuanced in its comparison of doctrinal and economic analysis, but even so, efficient breach makes the following appearance:

'The difference between doctrine and classical economic analysis in contract is easily summarised. Efficient breach in response to unexpected and disproportionate costs of performance is protected by the undue hardship defense to specific performance. So-called "efficient" breach to accept a higher price offered by a third party is not the law and never has been the law. But that's a different article.'

Laycock (n 15) 27-8 (footnotes omitted).

${ }^{88}$ Eric Posner has levelled a similar criticism at contracts casebooks:

'Contract-law casebooks and treatises show the influence of economics, but it is the influence of pre-1980 economics. Most casebooks and treatises mention the idea of efficient breach, but not the equally important idea of efficient reliance. Casebooks generally treat the economic approach as an exotic "perspective," as an object at which to marvel, and not as the underlying logic of contract law.'

EA Posner, 'Economic Analysis of Contract Law after Three Decades: Success or Failure?' (2003) 112 Yale LJ 829, 869 (footnote omitted).

${ }^{89}$ The first idea came from a comment by Aziz Huq on another paper, and the second from discussions with Alex Stremitzer.

${ }_{90}$ Bray (n 78) 563-72.

91 This list of only three actors depends on two assumptions: first, the court has not appointed its own officer, such as a master or receiver; and secondly, there is no agency-cost problem. In some remedial situations the agency-cost assumption will be untenable. MW McConnell, 'Why Hold Elections? Using Consent Decrees to Insulate Policies from Political Change' (1987) U Chi Legal F 295.

${ }_{92}$ That injunctions can succeed or fail may seem obvious, but the idea of an injunction's failure is rarely discussed, at least outside of an anomalous American remedy, the 'structural injunction'.
} 
motivations can also change over time, as the parties share or withhold information, as they learn or as the circumstances change. Because the contents of an injunction are a matter of deliberation and strategy, one criticism of game theory would not be applicable, namely that human decisions are not in fact strategic. ${ }^{93}$

2. A plaintiff seeking a declaration often does so to resolve legal uncertainty. The plaintiff might want to know whether a contemplated act would breach a contract, infringe a patent or violate a criminal statute-having that knowledge today could help him avoid a highly unpleasant tomorrow. ${ }^{94}$ A person who contemplates seeking a declaration might consider not only the value of resolving the uncertainty but also its costs, including the costs of litigation. Besides these considerations, however, there is an intriguing question about whether the timing of the resolution of the uncertainty-before or after the possible breach, infringement or criminal act-affects the merits of the resolution. ${ }^{95}$ What do we know about whether, all else being equal, a party has a greater chance of success if presenting the claim in the posture of an ex ante action seeking a declaration or in the posture of an ex post defence to an enforcement action? We know almost nothing. ${ }^{96}$

One could imagine two different hypotheses to test in a laboratory experiment. One is that asking for permission will make the court think that the plaintiff is officious or meddling, the sort of person who plays close to the line. ${ }^{97}$ On that hypothesis, all else being equal, a litigant should be less likely to win by seeking a declaration than by waiting and making the same argument in a later defence. But the opposite hypothesis is also possible, and to my mind is more likely to be right. That is, there could be a cookie-jar effect. Asking permission to eat a cookie is better than getting caught with your hand in the cookie jar. A plaintiff seeking a declaration of non-infringement of a patent is asking permission, whereas a defendant who is being sued for patent infringement has been caught with a hand in the cookie jar.

Scholars who write about declarations could benefit from the answer to the question. Yet answering the question requires a different set of skills and

\footnotetext{
93 eg GM Lucas, MD McCubbins and M Turner, 'Against Game Theory' in RA Scott, SM Kosslyn and N Pinkerton (eds), Emerging Trends in the Social and Behavioral Sciences: An Interdisciplinary, Searchable, and Linkable Resource (John Wiley 2015) (calling chess and similar games of strategy 'perhaps the last place one should look for a model of human decision-making generally'). That said, an analysis of the interactive decision making of the plaintiff, defendan, and judge might consider other points advanced by Lucas, McCubbins and Turner, including domain-specificity, the possibility of learning, institutions and the influence of the judge's identity on the judge's decision making.

${ }_{94}$ Bray (n 60); see also SL Bray, 'The Myth of the Mild Declaratory Judgment' (2014) 63 Duke LJ 1091, $1117-19$.

95 Other points of difference between the earlier and later resolution include variation in the quality and amount of evidence, and sometimes shifts in the burden and quantum of proof.

${ }_{96}$ The only evidence appears to be KA Moore, 'Judges, Juries, and Patent Cases-An Empirical Peek Inside the Black Box' (2000) 99 Mich L Rev 365, 368.

${ }^{97}$ In Aristotelian terminology, a 'stickler for his rights'. D Klimchuk, 'Aristotle at the Foundation of the Law of Equity' in Klimchuk, Samet and Smith (n 5).
} 
knowledge: not the analysis of remedies doctrine, but expertise in experimental economics.

\section{Explanations}

So what exactly explains the failure of the two disciplines to talk to each other? It should be clear that the impediment to conversation is not merely terminological: you say tomato, I say tomato, you say injunction, I say property-rule protection. In US law, economic analysis has had significant influence in antitrust, contract and tort, and in none of them was there preexisting overlap in terminology between doctrinal and economic scholarship.

Maybe an explanation lies in the direction of 'two cultures'. ${ }^{98}$ There are different typical paths to the academy for US scholars who self-identify in law and economics and in remedies, and different typical sets of skills and kinds of knowledge.

Yet another explanation might be the tendency of some law and economics scholars to begin with a model of what would be socially optimal. ${ }^{99}$ Although they may then discuss the divergence of the law from the model ${ }^{100}$ the tendency to start with the model leads to less attention to doctrinal details. ${ }^{101}$

Alternatively, the explanation might be one that can be generalised to many kinds of disciplinary fragmentation: time and attention are scarce. As specialisations narrow and their bodies of literature grow, keeping up becomes more difficult.

Although each of these explanations may have merit, especially the point about scarcity of attention and specialisation of fields, they tend to shift the puzzle rather than solve it. The question remains why these differences seem to have a larger effect in remedies than in other areas of the law.

The fields both talk about the same thing, but they see the goal of the judicial enterprise quite differently from that of the scholarly enterprise. In the field of remedies, the primary remedial goal is generally thought to be the rightful position, ie 'the position the plaintiff would have been in but for the wrong. ${ }^{102}$ A remedy is a remedying, a putting back together again, however imperfectly. The perspective adopted is more likely to be an internal one, adopting the law's own structures and categories of thought. ${ }^{103}$ In economic

\footnotetext{
98 CP Snow, The Two Cultures (CUP 1998). There are also two-culture problems within law and economics itself. A Schwartz, 'Two Culture Problems in Law and Economics' (2011) U Ill L Rev 1531.

${ }_{99}$ eg Polinsky and Shavell (n 68).

100 Polinsky and Shavell (n 68) 896-900. On evaluating the divergence of the law from a model, see Calabresi (n 62).

${ }^{101} \mathrm{cf}$ C Saiman, 'Restitution in America: Why the US Refuses to Join the Global Restitution Party' (2008) 28 OJLS 99, 117-19 (contrasting the analysis of restitution by Peter Birks with that of American law and economics scholars).

${ }^{102}$ Laycock (n 55) 14. For sources discussing the importance of also considering the rightful position of the defendant, see n 69 .

${ }^{103}$ HLA Hart, The Concept of Law (3rd edn, OUP 2012) 88-91.
} 
analysis, the goal of a remedy is generally thought to be the minimisation of social costs, with optimal deterrence being a crucial means for that end. The perspective adopted is typically an external one, evaluating the consequences of legal decisions.

These different perspectives give a different shape to the work-as do the different goals of making the plaintiff whole and deterring would-be violators in the future. ${ }^{104}$ Of course, an award of damages might do both of these things, making whole and deterring. ${ }^{105}$ Which of these goals a scholar has in mind will drive the analysis. As their analyses diverge, remedies scholars may be put off by what they rightly perceive as the basic misdescription of remedies in some economic scholarship, and economists may be put off by what they rightly perceive as the narrowly doctrinal quality of some remedies scholarship.

\section{Prescriptions}

These divergences in aim and perspective can explain, but not justify, the lack of robust conversation between law and economics and the field of remedies. There is disagreement about whether to evaluate law using its own structures and categories of thought or to evaluate it with reference to external criteria, and there is disagreement about the goals for a remedy. Even so, there are too many questions about which these groups of scholars can usefully converse and collaborate. ${ }^{106}$ Legal scholars who work on remedies can engage scholars working in law and economics more directly, and a good model for this is Douglas Laycock's article on the undue-hardship doctrine. ${ }^{107}$ We can make more use of economic concepts, especially ones that are not gathering dust. Efficient breach has had enough play. Other concepts hold more promise for remedies, as does experimental economics.

In addition, there are many remedial doctrines that are not really about the rightful position. Consider, from the law of damages, the constraints of certainty, remoteness and mitigation, ${ }^{108}$ as well as the economic-loss rule, the restriction on damages for emotional harm in contract and the collateral-source rule. ${ }^{109}$ None of these doctrines is easily explicable in terms of the rightful

\footnotetext{
${ }^{104}$ M Stone, 'On the Idea of Private Law' (1996) 9 CJLJ 235, 239 fn 18.

105 In other ways, too, there can be partial convergence. A scholar in law and economics could find the goal of the plaintiff's rightful position to be generally efficient: it avoids distortion of individuals' decisions about which activities to engage in (see n 67), offers a salient measure of recovery and perhaps fosters popular acceptance of the civil justice system. A scholar in the field of remedies would have to concede that there are constraints on the pursuit of the rightful position, and that some of the constraining doctrines are meant to alter the incentives of the parties.

${ }^{106}$ The point that remedies can draw in a qualified way from economics is not new. eg DR Harris, 'Remedies: Canadian Viewpoints (1987) 7 OLJS 465, 466 (reviewing Sharpe, Injunctions and Specific Performance and Waddams, Law of Damages). On convergence and rapprochement between the internal and external perspectives, see AS Gold and HE Smith, 'Sizing Up Private Law' (2017) SSRN Working Paper.

${ }^{107}$ Laycock (n 15).

108 These are discussed under the heading 'Limiting Principles' in pt III of SM Waddams, Law of Damages (5th edn, Thomson Reuters 2012).

109 These doctrines and others are discussed under the heading 'Limits on Damages' in ch 1 of Laycock (n 55).
} 
position. ${ }^{110}$ All of them can be supported by an appeal to consequences. ${ }^{111}$ Similarly, there are many equitable doctrines that focus less on restoring the plaintiff's rightful position and more on the promises the court is making - and whether it is prudent for the court to make them. These include equitable ripeness, the specificity requirement, the adequacy requirement, the propensity requirement, injunction bonds, some uses of the equitable defences and some of the equitable maxims that counsel restraint. ${ }^{112}$

The common theme in all of these doctrines is that they do not pursue the rightful position as much as they bound that pursuit. They often bound that pursuit for prudential or consequentialist reasons (though sometimes for nonconsequentialist moral reasons). Scholars of remedies and of economics can work together on these prudential or consequentialist constraints even without agreement about ultimate goals. Moreover, this point can be generalised: because the prudential or consequentialist constraints on remedies are embedded in the law itself, they can be a joint subject of inquiry for scholars who adopt an internal perspective on the law and those who adopt an external perspective.

Now what does each side have to gain from cooperation? What scholars working on remedies have to gain is clear: they can get help with conceptualising and solving stubborn problems, like the paradox of equitable remedies or the possible effect that the declaration posture has on merits determinations.

But what do the economists have to gain from remedies scholars, and from taking the law of remedies more seriously? One answer is simply more problems to work on. For example, a scholar could employ behavioural economics to analyse the decisions a judge makes when issuing and enforcing an injunction, or a scholar could examine whether litigation costs or outcomes are different in states that do not have punitive damages. ${ }^{113}$ There are also many remedies that have received scant attention in the economic literature. These include nominal damages, replevin, mandamus, habeas, declarations and accounting for profits. Some of these remedies have been obscured simply by the use of labels. For example, one reason that restitutionary remedies have received less careful attention in the economic literature is the tendency to invoke a generic remedy of 'disgorgement" ${ }^{\text {'14 }}$ - which has no basis in the

110 cf City of Salinas v Souza and McCue Construction Co, 424 P 2d 921, 926-7 (California 1967) (describing the collateral source rule as 'punitive in nature' because it forces 'the wrongdoer [to] pay damages for an injury which may have been already compensated in whole or part'). In contract law, the contemplation-of-the-parties limit associated with Hadley $v$ Baxendale is easier to fit within the analysis of the plaintiff's rightful position.

111 eg CT McCormick, 'The Standard of Certainty in Measurement of Damages' (1934) 43 Yale LJ 1109, 1115 (stating that the reasonable-certainty requirement 'was developed, and has been used, chiefly as a convenient means for keeping within the bounds of reasonable expectation the risk which litigation imposes upon commercial enterprise').

${ }^{112}$ For discussion of some of these doctrines, see Bray (n 78) 572-86. On the equitable maxims, see Heydon, Leeming and Turner (n 22) \$3-005-\$3-275, 68-102.

113 On variety in state law about the availability of punitive damages, see Exxon Shipping Co v Baker, 554 US 471,495 (2008).

114 eg Y Givati and Y Kaplan, 'Over-Reliance under Contractual Disgorgement' (2017) American Law and Economics Review (forthcoming); BI Huang, 'The Equipoise Effect' (2016) 116 Colum L Rev 1595. More circumspect usage is found in DB Kelly, 'Remedies for Breach of Trust' (2017) SSRN Working Paper, 
common law or equity ${ }^{115}$-instead of more specific and well-established restitutionary remedies. For American lawyers, these remedies include accounting for profits, constructive trust, equitable lien, rescission in equity, rescission at law, recovery in quasi-contract and so on. ${ }^{116}$ Different restitutionary remedies have different requirements, limitations, strengths, and implications for bankruptcy and for the jury trial right. ${ }^{117}$ By ignoring their existence, economic scholars are missing the granularity of the law.

However, economists have more to gain than just additional problems. Think back to 'The Cathedral'. Its model of property rules and liability rules is an abridgment that leaves out many details of legal doctrine. That abridgment is what gives the model its portability. It has allowed scholars to employ the model widely. To assess such an abridgment, the question is always whether what is left out is mere detail or rather crucial points of structure and shape. As Thomas Merrill and Henry Smith have said, when offering certain criticisms of the treatment of property in economic scholarship,

Every theory must abstract away from certain details. But by systematically abstracting away from the in rem feature of property rights, law and economics has blinded itself to certain features of property regimes - features that are important and cannot be accounted for on any other terms. ${ }^{118}$

where 'disgorgement' is an umbrella term for 'any remedy that allows a plaintiff to strip a defendant's ill-gotten gains, including legal restitution, accounting for profits, the constructive trust, and equitable lien'. Nevertheless, the term 'disgorgement' is a source of pervasive confusion. Except where authorised by statute, it should be retired in favour of more specific categories such as (in US law) 'accounting' and 'quasi-contract'.

115 cf SM Bainbridge, 'Kokesh Footnote 3 Notwithstanding: The Future of the Disgorgement Penalty in SEC Cases' Washington University Journal of Law and Policy (forthcoming) (noting the US Supreme Court's recent scepticism of disgorgement where not authorised by statute); GP Roach, 'A Default Rule of Omnipotence: Implied Jurisdiction and Exaggerated Remedies in Equity for Federal Agencies' (2007) 12 Fordham Journal of Corporate and Financial Law 1, 49 ('As applied in any context, "disgorgement" was used in less than a dozen federal or state case opinions from 1800 to 1960 . Perhaps more startling is the fact that the term was used so often between 1960 and 2000 even though the first proposed definitions only began to appear around 2000. The term was not used or defined in the Restatement First and was only defined in a draft of the Restatement Third as of 2000. Black's Law Dictionary only offered a definition after 2000').

${ }^{116}$ For readers familiar with the last few decades of scholarship on unjust enrichment, especially in England, Canada and Australia, several entries in this list may seem provocative or erroneous. My point here is not to present an argument for the remedial constructive trust, the retention of quasi-contract or the classification of rescission as restitutionary; rather, it is to point out that these remedial categories are used by courts in the United States but are largely ignored in law and economics scholarship.

${ }^{117}$ For summaries of the restitutionary remedies in UK law, see G Virgo, Principles of the Law of Restitution (3rd edn, OUP 2015) 18-23. For US law, an overview of the terms and contours of the legal and equitable restitutionary remedies can be found in Sherwin and Bray (n 22). The leading authority on restitutionary remedies in US law is, of course, the Restatement of the Law Third Restitution and Unjust Enrichment (ALI 2011) (3rd Restatement). Note, however, that the 3rd Restatement follows the prevailing doctrinal categories more closely in its sections on the equitable remedies of constructive trust, equitable lien and subrogation than it does when reluctantly distinguishing legal and equitable remedies and when lumping together all cases of conscious wrongdoing (equating for this purpose the equitable remedy of 'accounting' with 'disgorgement' in s 51(4)). To an extent not apparent from the $3 r d$ Restatement, US courts continue to distinguish between the legal and equitable restitutionary remedies, and continue to use traditional terminology (eg accounting, rescission at law, rescission in equity, quasi-contract, quantum meruit, money had and received). Sherwin and Bray (n 22); Bray (n 78) 553-6.

118 TW Merrill and HE Smith, 'What Happened to Property in Law and Economics?' (2001) 111 Yale LJ $357,398$. 
When economists have discussed remedies, they have sometimes neglected certain basic features, including the distinctive characteristics of equitable remedies that are elided by 'The Cathedral'. These are not surface details, but are part of the deep structure of the law of remedies. ${ }^{119}$ If economists want to influence that law, they need to grasp its structure. This point is illustrated by eBay Inc $v$ MercExchange, $L L C,{ }^{120}$ a major US case about the availability of injunctions, particularly in patent litigation. Many scholars had previously written about the economics of patent remedies, but when the US Supreme Court decided eBay, it did not invoke those economic analyses. Instead, it repeatedly invoked what it considered traditional equitable doctrine. ${ }^{121}$ Some readers may find it surprising that the US Supreme Court would invoke traditional equity, but doing so was consistent with the Court's sustained emphasis on the historic distinction between law and equity. ${ }^{122}$

It is too much to hope for a full unification of scholarship in economics and scholarship in remedies. More generally, it is too much to hope for a full unification of the internal and external perspectives on the law. The aims and perspectives are just too different. It is not, however, too much to hope for more, and better, conversation. Talking would be Pareto superior.

119 Bray (n 78).

120547 US 388 (2006).

121 For diverging assessments of how well the Court stated the traditional equitable doctrine, see Bray ( $\mathrm{n}$ 5); Laycock (n 55) 426-7; MP Gergen, JM Golden and HE Smith, 'The Supreme Court's Accidental Revolution? The Test for Permanent Injunctions' (2012) 112 Colum L Rev 203.

122 JF Duffy, 'Administrative Common Law in Judicial Review' (1998) 77 Tex L Rev 113, 126-9; Bray (n 5). 